\title{
Introduction to the Four Kingdoms as a Time Bound, Timeless, and Timely Historiographical Mechanism and Literary Motif
}

\author{
Andrew B. Perrin
}

New Directions for a Discussion on Four Kingdoms

This collection of essays is the result of a collaborative project between Ludwig-Maximilians-Universität München and Trinity Western University. Our venture began as a small conference in Munich (August $7-8,2018) .{ }^{1}$ The outcomes of our conversations there both answered questions and posed new ones. As such, we extended invitations to a larger group of scholars to include voices that were both international and interdisciplinary. The topic that united all of these contributions was the historiographical mechanism and motif of the four kingdoms.

The four kingdoms schema has enabled writers of various cultures, times, and locations, to periodize all of history as the staged succession of empires barreling towards the consummation of history and arrival of a utopian age. The motif provided order to lived experiences under empire (the present), in view of ancestral traditions and cultural heritage (the past), and inspired outlooks assuring hope, deliverance, and restoration (the future). Research on the historical origins, imperial identifications, history of interpretation, and contemporary applications of the four kingdoms pattern is expansive. ${ }^{2}$ The present project both draws upon and extends these studies on the mechanism's formulation and reformation before, in, and beyond the book of Daniel in three key ways.

First, research on the four kingdoms traditionally adopts a quest for origins approach. That is, pursuing and identifying the earliest expressions of this idea-whether in known external sources or redactional histories of biblical

1 Funding for the event was provided by the Canada Research Chair in Religious Identities of Ancient Judaism at Trinity Western University, the Chair of New Testament Studies at Ludwig-Maximilians-Universität München, and the Alexander von Humboldt Stiftung.

2 Given that the four kingdoms pattern cuts across many ancient writings, amassing a comprehensive bibliography is challenging and will inevitably leave something out. For studies representative of the scope of texts, questions, and approaches of four kingdoms research, see the bibliography at the end of this introduction. The bibliographies of individual essays in the volume complete the state of research as it relates to specific collections or periods. 
writings-is understood as the interpretive solution to unlocking the overarching meaning of this notion. As seen in the bibliography below, several important studies have revealed that there are discernable ancient historiographical attempts at kingdom counts in both ancient Near Eastern and Hellenistic writings. Examples such as the Bahman Yasht (Zand-ï Vohüman Yasn) and Hesiod's Works and Days 1.109-201 are often considered indicators for this foundational point of departure for origins-oriented research. However, regardless of its beginnings, the four kingdoms motif has acquired a remarkably broad reach and diverse reception. Our project aims to balance the important quest for origins with new questions that focus more on the ongoing development of four kingdoms schemas.

Second, due to Daniel's privileged place in the Jewish and Christian canons, this writing became the main channel by which Western intellectual culture and confessional communities received and encountered this type of imperial periodization. It would not be too much to say that it has become synonymous with Danielic tradition. To be sure, examples such as 4 Ezra 12:11 and Ant. 10.272-76; 11.337-338 indicate that, from an early time, writers engaged and extended Danielic concepts of empire and time. Yet in the larger lifespan of the four kingdoms motif, it is apparent that the concept is bound neither to Danielic tradition itself nor to a biblical book. It exists not only before the biblical book, as noted above, but is also beyond it. Our project aims to extend the scope of writings and corpora considered in the origins, transmission, and reception of four kingdoms motifs.

Third, studies on the redaction through reception of the motif tend to look at the four kingdoms through the lens of Western cultural memory and media. Whether in materials from antiquity, the mediaeval period, or contemporary movements, the four kingdoms structure fueled the imaginations of creators of any ilk and communities of all traditions. The recent discovery of four beasts imagery and an accompanying Aramaic inscription in a fifth century CE floor mosaic at the synagogue at Huqoq offers evidence for an early cultural appropriation of the concept in visual architecture. ${ }^{3}$ Closer to our own time, a dangerous interpretation of Danielic historiographies contributed to the apocalyptically-charged ideology of the Branch Davidians. ${ }^{4}$ There are, of

3 The full nature of the discovery with images must await the dig report. In early news releases, Jodi Magness confirmed an image of the second beast of Dan 7:4 as well as a partial Aramaic inscription referring to the first beast. See Amanda Borschel-Dan, "First Artistic Depiction of Little Known Exodus Story Uncovered in Galilee," The Times of Israel, 1 July 2019, https://www .timesofisrael.com/first-artistic-depiction-of-little-known-exodus-story-uncovered-at-huqoq.

4 For example, the controversial posthumous music release of David Koresh's original songs includes a track titled, "The Book of Daniel." See Steve Hochman, "Is the Pop World Ready for 
course, many more expressions of the four kingdoms between these bookends of beauty and tragedy in Western culture. Yet a Western orientation risks overlooking or ignoring equally numerous non-Western cultural expressions that found or made meaning by drawing on the patterning of world history by a four kingdoms count. The sample pairing here also illustrates the need to engage more than written materials to account for other types of cultural appropriations or redeployments. Our project aims to expand the cultural conversation partners to include overlooked or ignored items relevant to the study of the four kingdoms outside of the West.

\section{Volume Overview}

No single essay in the volume achieves all of the above aims. Rather, the collection of thirteen essays below demonstrates the importance of interdisciplinary dialogue and collaborative research to both fill current gaps in knowledge and to create new questions around the arc of four kingdoms expressions across cultures, corpora, and chronologies. Our contributors achieve this in the following ways.

Michael Segal ("The Four Kingdoms and Other Chronological Conceptions in the Book of Daniel") considers five aspects of Daniel's chronological infrastructure: chronological span, periodization, determinism, geopolitical transformation, and eschatology. In the course of this investigation, Segal advances several key observations related to the compositional-exegetical growth of the tradition. In particular, he notes the symbolic culmination and continuation of empires until their collective destruction in Daniel 2 and 7 and demonstrates how the succession of empires motif in Daniel 8 has influenced interpretations of the earlier Aramaic four kingdoms traditions. Segal also underscores how inner-biblical interpretation was a driving compositional force for the Danielic apocalypse, which has, at times, resulted in harmonistic exegesis.

Ian Young ("Five Kingdoms, and Talking Beasts: Some Old Greek Variants in Relation to Daniel's Four Kingdoms") uses textual variants to recover aspects of Daniel's rolling redaction and reception. He argues that a comparative

David Koresh?" Los Angeles Times, 3 April 1994, https://www.latimes.com/archives/la-xpm -1994-04-03-ca-41504-story.html. In a lyrical rat nest of blended biblical allusions, Koresh in one instance sings: "Babylon's number four, gonna come to the ground." This seems to draw upon the division of the great city into three parts, with Babylon receiving her destruction thereafter in Rev 16:17-20. The confused connections between Revelation and Daniel in the song are occasioned by the identification of the book of Daniel as the writing held by the angel in Rev 10:8. 
commentary approach to the variants of Daniel will open up fresh perspectives on how individual witnesses or traditions give voice to their particular message among the chorus of Daniel materials from antiquity. Through discussion of select examples between OG and MT witnesses to Daniel, Young demonstrates how the Hebrew tradition occasionally includes adaptations and revisions of the four (or five) kingdoms schema as recovered from the Greek. In this way, traditional text-critical approaches prioritizing Mт have overlooked how that tradition is also a site of reception and interpretation of earlier materials.

Using methods of the emerging field of animal studies, Alexandria Frisch ("The Four [Animal] Kingdoms: Understanding Empires as Beastly Bodies") considers Danielic discourses on empire by exploring the human and beastly bodies that pervade the book's four kingdom motifs. In this process, the symbolic nature of the animalistic imagery takes on new significance as empires are not only likened to features associated with ravenous animals-for the Danielic tradition, the empires roving the ancient Near East and Mediterranean were hybrid wild animals. When considered in the larger chronological and symbolic complexes of other ancient Jewish apocalypses, including 4 Ezra and the Animal Apocalypse of 1 Enoch, Frisch underscores how this understanding in Daniel coheres with other views of antediluvian expressions and eschatological embodiments of empire.

Loren Stuckenbruck ("The Apocalypse of Weeks: Periodization and Tradition-Historical Context") articulates the multi-tiered historiographical structures of the Enochic Apocalypse of Weeks and finds that, while there is no explicit four kingdom scheme within the work, the understanding and order of eras in Enochic tradition invites comparison with other ancient structures of time. These include variations within Enochic tradition itself (e.g., the Animal Apocalypse) as well as other enumerations of history in numbered periods (e.g., Daniel and Sibylline Oracles). In the course of these comparisons, Stuckenbruck notes the extent and limits of the often-assumed influence of Danielic chronologies on other historiographical structures in ancient Jewish writings. In view of his internal analyses of Apocalypse of Weeks and external comparisons, Stuckenbruck concludes the work "remains distinct" in its combination of numerical structures, making it "difficult to speak of traditions that have either influenced Aw directly or have been influenced by it."

Andrew Perrin ("Expressions of Empire and Four Kingdoms Patterns in the Aramaic Dead Sea Scrolls") demonstrates how the Aramaic writings among the Qumran collection evidence early uses and formulations of four kingdoms historiographies. Prior to the discovery of these writings from the Judaean wilderness, the book of Daniel included the principle Aramaic participant in this historiographical strategy in ancient Judaism. Some writings, such as the aptly 
named 4QFour Kingdoms, however, likely extended a traditional chronology under a new imperial present under Rome apart from a discernable Danielic influence. Other Aramaic writings with less likely four kingdoms structuressuch as New Jerusalem, Tobit, and Pseudo-Daniel—are shown to provide a larger context for studying scribal conceptions of time, history, and chronology in Aramaic compositional milieus. In this, the bridge of the four kingdoms motif into ancient Judaism was built by Aramaic scribal culture. Daniel, it seems, was but one traveler among a now larger known set of writings with analogous historiographical inclinations.

Olivia Stewart Lester ("The Four Kingdoms Motif and Sibylline Temporality in Sibylline Oracles 4") revisits the imperial chronologies of Sibylline Oracles 4 by reading the motif both backwards and forwards in the formation of the tradition. This involves recovering the patterns of four and five kingdoms frameworks within the ten-generation count as well as projecting the interpretive vistas these layered political historiographies opened for audiences through reception history. Interacting with the recent work of Paul Kosmin on conceptions of time and historiography in response to Seleucid rule, Stewart Lester argues that Sibylline Oracles 4 challenges core aspects of his proposal: the text both participates in the continuation of prophecy in ancient Judaism and embraces a large scope of imperial histories in its prophetic construction of time. As a result, she demonstrates how the "fragmented, multiple, non-linear temporality that results from the transformation of the four kingdoms motif in Sib. Or. 4" establishes a determined and disorienting prophetic outlook.

Kylie Crabbe ("The Generation of Iron and the Final Stumbling Block: The Present Time in Hesiod's Works and Days 106-201 and Barnabas 4") explores the enumeration of generations in Hesiod's Works and Days in order to trace the patterns of decline, resurgence, and comment on the vices of the author's contemporary world as well as the non-temporal elements that figure in the schema. In view of this re-evaluation of one of the earliest known representations of this historiographical mechanism, Crabbe tracks temporal recalibrations in writings of Virgil and Ovid as they reimagine the golden age, construct triumphalist outlooks, and reinterpret a static past as culminating in their presents on the brink of a decisive transition. With this background in place, Crabbe then studies how Epistle of Barnabas 4 understands Danielic timetables in order to demonstrate the acceptance of past revelation but refutation of earlier interpretations of Hebrew Scripture. In this respect, Barnabas is an example of the reception of a chronological mechanism that provides both a structure of broader time and a sense of its ever-imminent culmination.

Katharina Bracht ("The Four Kingdoms of Daniel in Hippolytus's Commentary on Daniel") considers the interpretive interface of Jewish scripture 
and early Christian exegesis in the earliest, complete commentary on Daniel, dated to $204 \mathrm{CE}$. Here too, the antique author's awareness of the extent and limits of the four kingdoms chronology demanded a reconfiguration of earlier kingdoms in the schema to open up the fourth slot accommodating the Roman Empire. Hippolytus's overcoming of the temporal and cultural distance with the early Daniel materials was largely informed by the reception of Daniel texts in the New Testament. As a result, Hippolytus reframed the four kingdoms structure into new political and theological domains related to the emergence of Roman dominion, roles of an Antichrist, and ascendency of divine rule at the second coming. Bracht also demonstrates Hippolytus's cultural encounters with his contemporaries caught up in imminent end-time calculations, particularly those of Montanist leanings. For Hippolytus, the theological issue was less about determining when such events will occur than in having confidence that they will transpire as prophesied in Daniel's convergence of the earthly and eschatological.

Geoffrey Herman ("Persia, Rome and the Four Kingdoms Motif in the Babylonian Talmud") reconsiders the rejection of the apocalypse genre and exegesis of the four kingdoms tradition in rabbinic tradition regarding debates over the exchange of rule between Rome and Persia. Herman considers both a traditional and geographical divide that informed rabbinic receptions of the chronology by recovering varying interpretive perspectives between materials cultivated in Palestinian vs. Babylonian milieus. He uncovers how one's cultural and chronological setting within the broad empires of the Near East informed the perspective on the emergence, continuation, and (non)cessation of ancient superpowers. In the east, the shift from Babylon to Persia was likely most perceptible. In the west, the exchange from Greece to Rome was no doubt most evident. As a result, in addition to varying perceptions of empire and perspectives on their geopolitical exchanges, rabbinic thought offered a number of expectations of the end of empire.

Lorenzo DiTommaso ("The Four Kingdoms of Daniel in the Early Mediaeval Apocalyptic Tradition") plots the emergence and afterlives of the four kingdoms motif in a long arc of apocalyptic historiographies into the twelfth century. Following case studies on three mediaeval Daniel apocalyptica- two Syriac apocalypses of Daniel and the Apocalypse of Pseudo-Methodius-he asserts that the political-theological concept of translatio imperii that flourished in the mediaeval period extended out of the notion of diminishing rules until the eschatological age. Conceptions of empire, kingdoms, and ages in this era, however, were multivalent and almost always contingent upon the orientation, even location, of writers and rulers in Europe, Africa, and the Middle East. In these larger enterprises of imperial exchange and evolution, the four kingdoms 
motif served to support and differentiate identities of insiders and outsiders, eventually giving way to understandings of the transfers of civilization between ages. This ongoing speculation and reorientation, DiTommaso argues, reveals a fundamental pair of functional modalities of apocalyptic speculation birthed in mediaeval scholarship, namely "revolutionary" and "imperial."

Miriam Hjälm ("The Four Kingdom Schema and the Seventy Weeks in the Arabic Reception of Daniel") maps the patterns of political prediction and time structures enabled by Danielic schemas in pre-modern Arabic Daniel translations. Hjälm establishes the larger framework of Judaeo-Arabic commentaries, Islamic redeployments of the mechanism, varied Vorlagen of Daniel available to translators and communities, and even the expansion of the Danielic visionary cycle. Within this larger complex of texts and traditions, Hjälm reveals how "[t]hrough converts, polemics, and candid inquiry, literary motifs and philosophical ideas easily traversed confessional borders and were adapted to fit new life-worlds." In this way, a historiographical mechanism which begins in antiquity extends across diverse linguistic, cultural, geographical, and religious axes of reception history.

James Hamrick ("Conflicting Traditions: The Interpretation of Daniel's Four Kingdoms in the Ethiopic Commentary [Tergwāmē] Tradition") presses into an uncharted area of biblical reception history and cultural studies by exploring the Ethiopic commentary traditions related to Daniel. These interpretive traditions that took shape in northern Africa maximized the uninterpreted elements of Daniel's dream-visions to update and adapt the geopolitical vision of the text to a variety of kings and empires from antiquity through the Islamic periods. In some instances, the Ethiopic commentaries are also repositories of reception and debate with other early commentators, such as Hippolytus of Rome. In others, they represent an internal variety of four kingdoms configurations coexisting within a single commentary tradition.

Brennan Breed ("The Politics of Time: Epistemic Shifts and the Reception History of the Four Kingdoms Schema") sets the discussion of the four kingdoms in reception history within a broader theoretical framework of conceptions, articulations, and organizations of time. Using the notion of chronosophythe synthesis and expression of a purpose of history - as a departure point, Breed unpacks the political potential of the four kingdoms mechanism for orchestrating time, establishing identities, and affirming control in the diverse reception of Daniel. Breed recovers various inflected readings of the four kingdoms in classical through mediaeval thinkers in Jewish and Christian traditions as well as in Western cartographical representations and technological innovations. Though diverse in their orientation and understanding of the four kingdoms scheme, these channels of reception document the malleability of 
the mechanism as individuals, movements, and nations re-assigned and reconfigured kingdoms for claims of local and universal sovereignty.

These essays both revisit traditional texts essential to four kingdoms research and reach into corpora and contexts yet to register in the discussion. Our efforts result in both new open-questions and outcomes. While the above essay summaries hint at such contributions worked out in the chapters that follow, it is helpful here to capture some of the impressions and ideas revealed by our collective exploration of the four kingdoms motif. Doing so at the outset is particularly relevant given the inherent interdisciplinarity of the project and hopefully helpful for setting a broader context for readers.

\section{$3 \quad$ Project Outcomes and Open Questions}

As noted above, this project aimed to recognize the origins of the four kingdoms motif but to also unmoor ourselves from them. One implication of this was discovering the generative quality of this classic historiographical mechanism. It not only catalyzed traditions in antiquity. It also enabled texts and communities to both recalibrate time and reimagine traditions in exceptionally diverse contexts. This underscores the inherent fallacy of reverse engineering traditions as the only, main, or even highest goal of research on the formation of texts and traditions. The essays below reveal that text-oriented questions are undeniably essential—in most cases, textual representations are our data - yet these find greater significance when merged with cultural studies. Simply put, while much of Daniel's four kingdoms chronologies hinge on events and individuals of the mid-second century BCE, often studied through the lens of Masoretic tradition, that context and this text account for a very small part of the ongoing four kingdoms traditions now available to us.

In various ways, our contributors revealed that the study of the four kingdoms motif in Daniel is also much more dynamic than often recognized. The time structures of Danielic four kingdoms motifs are multi-faceted. They both aided in forming the book and transforming it. This is evident in many ways, not least the surprising varieties of inner workings, or re-workings, of three, four, and five kingdoms historiographies in the manuscript traditions of the book of Daniel. As several contributors show, the four kingdoms in Daniel is not one thing. It is many things. Daniel's kingdoms chronologies are developed and framed differently in the Aramaic and Hebrew chapters, their representations in the Old Greek, and further still in Syriac, Arabic, and Ge'ez translations. In this way, it may be more appropriate to speak of the four kingdoms in Daniel as a complex of time structures and historiographies than as a singular 
motif. This requires a broader encounter with the multilingual manuscript traditions for the versions of Daniel without assuming or asserting the priority of a given form of the book.

It is abundantly clear that the four kingdoms motifs before and beyond the book of Daniel were recombined with other traditions as well as served as a way of recalibrating experiences and expectations. Because the motif is inherently bound to impressions or perceptions of empire, the four kingdoms complex provides a rich place to explore views from both east and west as well as from positions of both the powerful and powerless. The literatures studied below reveal how the four kingdoms served as a tool for ordering reality to numerous ends. These include: critiquing contemporary or historic empires, redeploying the identities and reassigning symbols of past empires for emerging ones, problematizing the very idea of empire as evil, legitimating regional sovereigns or those on the horizon, supporting or polemicizing religious movements or theological opponents, clustering existing four kingdoms interpretations, and creating new chronologies accounting for the ongoing translatio studii et imperii occasioned by geopolitical overturns or claims. Accounting for this complex goes beyond traditional exegesis. Forward movement on research on the four kingdoms must articulate how this mobile motif was appropriated in local contexts under varied religious and political authorities and was reimagined through cultural forces generating an endless arc of transmission and reception.

In these ways, our project finds a shared departure point in the four kingdoms yet travels outward from it in diverse directions. While the motif might feel familiar from the book of Daniel, our hope is that the present volume invites the readers into foreign spaces. These include deployments in classical and ancient Near Eastern writings, Jewish and Christian scriptures and interpretations, writings among the Dead Sea Scrolls, Apocrypha and pseudepigrapha, depictions in European architecture and cartography, and patristic, rabbinic, Islamic, and African writings ranging from antiquity through the Mediaeval eras.

\section{Bibliography}

Ballentine, Samuel. "The Future Beyond the End: Lessons from History by Herodotus and Daniel." PRSt 43 (2016): 145-59.

Baumgartner, W. "Zu den vier Reichen von Daniel 2." TZ 1 (1945): 17-22.

Bekkum, Wout van Jac. "Four Kingdoms Will Rule: Echoes of Apocalypticism and Political Reality in Late Antiquity and Medieval Judaism." Pages 101-18 in Endzeiten: 
Eschatologie in den monotheistischen Weltreligionen. Edited by W. Brandes and

F. Schmieder. мSснғм 16. Berlin: Walter de Gruyter, 2008.

Birks, T. R. The Four Prophetic Empires. London: Seeley, 1844.

Breed, Brennan W. "Daniel's Four Kingdoms Schema: A History of Re-writing World History." Int 71 (2017): 178-89.

Brummitt, Mark. "Four Empires VII. Literature." EBR 9:530-32.

Caquot, André. "Sur les quatre bêtes de Daniel VII." Sem 5 (1955): 5-13.

Caragounis, Chrys C. "Four Empires III. New Testament." EBR 9:519-2O.

Collins, John J. "The Place of the Fourth Sibyl in the Development of the Jewish Sybillina." JJS 25 (1974): 365-80.

Collins, John J. "Excursus: Four Kingdoms." Pages 166-70 in A Commentary on the Book of Daniel. Hermeneia. Minneapolis: Fortress, 1993.

Delgado, Mariano. "Four Empires V. Christianity." EBR 9:525-28.

Flint, Peter W. "Four Empires II. Greco-Roman Antiquity." EBR 9:518-19.

Flint, Peter W. "Four Empires IV. A. Second Temple and Hellenistic Judaism." EBR 9:520-22.

Flusser, David. "The Four Empires in the Fourth Sibyl and in the Book of Daniel." IOS 2 (1972): 148-75.

Gruenthaner, Michael J. “The Four Empires of Daniel." СвQ 8.1 (1946): 72-82.

Gruenthaner, Michael J. “The Four Empires of Daniel II.” свQ 8.2 (1946): 201-12.

Gurney, Robert J. M. “The Four Kingdoms of Daniel 2 and 7." Them 2 (1977): 39-45.

Hardt, Hermann von der. De Quatuor Monarchiis Babyloniae Pro antique Historiae Judaicae luce: Ad illustrandum Colossum in insomnio Nebucadnezaris Dan. II. Helmstedt: Hammius, 1708.

Hartman, Louis F. and Alexander A. Di Lella. Pages 30-33 in The Book of Daniel: A New Translation with Introduction and Commentary. Ав 23. Garden City, NY: Doubleday, 1978.

Hasel, Gerhard F. "The Four World Empires of Daniel 2 against Its Near Eastern Environment." JSOT 12 (1979): 17-30.

Hoonacker, A. van. "The Four Empires of the Book of Daniel." ExpTim 13 (1901-2): 42O-23.

Hoonacker, A. van. “L'historiographie du libre de Daniel." Le muséon 44 (1931):169-76. Jeong, Seong-Eun. "Four Empires I. Hebrew Bible/Old Testament." EBR 9:517-18.

Kaplan, Jonathan. "Four Empires IV.B. Rabbinic Judaism." EBR 9:522.

Kaplan, Jonathan. "Imperial Dominion and Israel's Renown: 'The Four Empires' in Mekilta deRabbi Ishmael." Pages 189-202 in Imagination, Ideology and Inspiration, Echoes of Brueggemann in a New Generation. Edited by Jonathan Kaplan and Robert Williamson, Jr. Sheffield: Sheffield Phoenix Press, 2015.

Kosmin, Paul J. Time and Its Adversaries in the Seleucid Empire. Cambridge, MA: Belknap Press of Harvard University Press, 2018. 
Kratz, Reinhard G. Translatio imperii: Untersuchungen zu den aramaischen Danielerzahlungen und ihrem theologiegeschichtlichen Umfeld. WMANT 63. NeukirchenVluyn: Neukirchener Verlag, 1987.

Kreß, Berthold. "Four Empires VIII. Visual Arts." EBR 9:532-33.

Melnyk, Janet L. R. "The Four Kingdoms in Daniel 2 and 7: Chapters in the History of Interpretation." PhD diss., Emory University, 2001.

Mendels, D. “The Five Empires: A Note on a Propagandistic 'Topos." AJP 102 (1981): 330-37.

Momigliano, Arnaldo. "The Origins of Universal History." Pages $133-55$ in The Poet and the Historian: Essays in Literary and Historical Biblical Criticism. Edited by R. Friedman. HSs 26. Chico, CA: Scholars Press, 1983.

Momigliano, Arnaldo. "Daniel and the Greek Theory of Imperial Succession." Pages 29-35 in Essays on Ancient and Modern Judaism. Translated by Maura MasellaGayley. Chicago: University of Chicago Press, 1994.

Newsom, Carol A. with Brennan Breed. "Excursus: Origin and Development of the Four-Kingdom Schema." Pages 8o-96 in Daniel: A Commentary. otL. Louisville: Westminster John Knox, 2014.

Niskanen, Paul. "Daniel and Classical Studies." Pages 26-43 in The Human and the Divine in History: Herodotus and the Book of Daniel. JSOTSup 396. London: T\&T Clark. 2004.

Noth, Martin. "The Understanding of History in Old Testament Apocalyptic." Pages 194214 in The Laws in the Pentateuch and Other Studies. Translated by D. R. Ap-Thomas. Edinburgh: Oliver \& Boyd, 1967.

Ozanne, Charles G. The Fourth Gentile Kingdom (in Daniel and Revelation). Worthing: Henry E. Walter, 1982.

Perrin, Andrew B. "(P)Reviewing the Course and Configuration of History through Dream-Vision Revelation." Pages 190-226 in The Dynamics of Dream-Vision Revelation in the Aramaic Dead Sea Scrolls. JAJSup 19. Göttingen: Vandenhoeck \& Ruprecht, 2015.

Peursen, Wido Th. van. "Daniel's Four Kingdoms in the Syriac Tradition." Pages 189-208 in Tradition and Innovation in Biblical Interpretation: Studies Presented to Professor Eep Talstra on the Occasion of His Sixty-Fifth Birthday. Edited by Wido Th. van Peursen and J. W. Dyk. Leiden: Brill, 2011.

Rappaport, A. "המלכות הרביעית בספר דניאל." BetM 10 (1964): 10-25.

Rivka, Raviv. "The Talmudic Formulation of the Prophecies of the Four Kingdoms in the Book of Daniel." JSIJ 5 (2006): 1-20 (Hebrew).

Rowley, Harold H. Darius the Mede and the Four World Empires in the Book of Daniel: A Historical Study of Contemporary Theories. Cardiff: University of Whales Press, 1935. Rubenstein, J. Nebuchadnezzar's Dream: The Crusades, Apocalyptic Prophecy, and the End of History. Oxford: Oxford University Press, 2019. 
Stevenson, W. B. "The Identification of the Four Kingdoms in the Book of Daniel." TGUOS 7 (1934-35): 4-8.

Swain, Joseph Ward. "The Theory of the Four Monarchies: Opposition History under the Roman Empire." CP 35 (1940): 1-21.

Tabarī, Muhammad al-. The Ancient Kingdoms. Vol. 4 of The History of al-Tabarī. Edited by Ehsan Yar-Shater. Translated and Annotated by Moshe Perlmann. Albany, NY: State University of New York Press, 1987.

Thomas, David. "Four Empires VI. Islam." EBR 9:528-30.

Travassos Valdez, Maria Ana. Historical Interpretations of the "Fifth Empire:" The Dynamics of Periodization from Daniel to António Vieira, S. J. S HCT 149. Leiden: Brill, 2010.

Walton, John H. "The Four Kingdoms of Daniel." JETS 29 (1986): 25-36.

Wechsler, Michael G. "Four Empires IV.C. Medieval Judaism." EBR 9:522-25.

Wiesehöfer, Josef. "Vom 'oberen Asien' zur 'gesamten bewohnten Welt': Die hellenistiche-römische Weltreiche-Theorie." Pages 66-83 in Europa, Tausendjähriges Reich und Neue Welt: Zwei Jahrtausende Geschichte und Utopie in der Rezeption des Danielbuches. Edited by Mariano Delgado, Klaus Koch, and Edgar Marsch. Stuttgart: Universitätsverlag Freiburg Schweiz, 2003. 